\title{
Assessment of bacterial pathogens on edible macroalgae in coastal waters
}

\author{
Olivia N. Barberi ${ }^{1}$ (D) Carrie J. Byron ${ }^{1} \cdot$ Kristin M. Burkholder $^{2} \cdot$ Adam T. St. Gelais $^{1,3}$ • Alicia K. Williams ${ }^{1}$
}

Received: 18 July 2019 / Revised and accepted: 8 November 2019 / Published online: 26 November 2019

(C) The Author(s) 2019

\begin{abstract}
In the Northeast USA, the aquaculture of macroalgae is a rapidly growing industry. Within this region, there are no established regulations for farm siting or methods of pathogen detection on macroalgae cultivated or harvested for human consumption. Bacterial pathogens from natural and anthropogenic sources may persist in coastal waters and can potentially contaminate macroalgae. During the winter growing season, sugar kelp Saccharina latissima and adjacent water were sampled from three sites of kelp aquaculture located in adjacent bays of ME, USA. Membrane filtration onto selective media detected Escherichia coli, Vibrio parahaemolyticus, and Vibrio alginolyticus in kelp and water samples at all sites, however plate counts were very low. The foodborne pathogens Salmonella enterica ser. Typhimurium, V. parahaemolyticus, and enterohemorrhagic E. coli O157:H7 were detected on enriched kelp samples from $83 \%, 78 \%$, and $56 \%$ of sampling events, respectively, using molecular methods. Even with low bacterial levels, this frequency of detection confirms the risk of foodborne pathogens present on kelp and recommends the development of best management practices to control microbial growth during kelp harvest and processing. Bacterial plate counts from kelp samples often varied from those of water, indicating the importance of sampling the kelp directly, and that the association between bacterial pathogens on kelp and in the surrounding water should be further investigated. This study provides the first food safety assessment of sea vegetables in this region with the goal of providing data to enable the expansion of its industry.
\end{abstract}

Keywords Macroalgae aquaculture $\cdot$ Sea vegetables $\cdot$ Kelp $\cdot$ Bacterial pathogens $\cdot$ Food safety

\section{Introduction}

Humans have consumed wild macroalgae for thousands of years and now cultivate many species through aquaculture processes (Wells et al. 2016). Aquaculture of macroalgae is dominant in the Asia-Pacific region where nori (Pyropia) and kelp (Saccharina japonica, Undaria pinnatifida) have been grown since the mid-twentieth century. Aquaculture has more

Electronic supplementary material The online version of this article (https://doi.org/10.1007/s10811-019-01993-5) contains supplementary material, which is available to authorized users.

Olivia N. Barberi

obarberi@une.edu

1 School of Marine Programs, University of New England, 11 Hills Beach Road, Biddeford, ME 04005, USA

2 Department of Biological Sciences, University of New England, 11 Hills Beach Road, Biddeford, ME 04005, USA

3 UNE NORTH: The Institute for North Atlantic Studies, University of New England, 1075 Forest Avenue, Portland, ME 04103, USA recently spread into North Atlantic countries, especially within the northeast region of the USA with the culture of sugar kelp (Saccharina latissima; Hafting et al. 2015; Cole et al. 2017). This region's market for edible macroalgae, termed sea vegetables, cultivated through aquaculture practices or harvested from wild beds, is growing in popularity due to macroalgal nutrient content, culinary potential, and sustainable farming practices.

Macroalgae harvested from coastal waters may grow near potential sources of bacterial human pathogens, but the risk of pathogen contamination has not been assessed. Food safety within the USA is regulated by the US Food and Drug Administration (FDA) which identifies bacterial contamination as a large concern, as 3.6 million foodborne illnesses are estimated to be caused each year by bacterial pathogens within the country (Scallan et al. 2011). Currently, the FDA addresses sea vegetables only through the approval of dried brown and red macroalgal species for the use of seasonings, spices, and flavorings and does not recognize these species as produce (U.S. FDA 2018). Guidelines for the detection of acceptable levels of human pathogens on sea vegetables are lacking yet 
are becoming increasingly necessary as the industry expands within the USA. As kelp and other sea vegetables from new and established farms or wild harvest companies continue to enter the edible products market, best management practices for harvest, transport, storage, and processing must be further established to ensure food safety.

Fecal coliforms are natural bacterial colonizers of mammalian digestive tracts and are therefore often found in estuarine and coastal environments. While fecal coliforms, such as Escherichia coli, are not necessarily pathogens themselves, they are indicators of fecal contamination. Therefore, presence of fecal coliforms in water or food indicates risk of contamination by gastrointestinal pathogens (Savichtcheva and Okabe 2006; Wu et al. 2011; Nevers et al. 2016; NSSP 2017). Bacterial pathogens of concern include the enterohemorrhagic E. coli strain $\mathrm{O} 157: \mathrm{H} 7$ that causes hemorrhagic colitis in humans and nontyphoidal Salmonella which is the leading cause of US hospitalizations and deaths from gastroenteritis (Labbé and Garcia 2013). Dominant pathways for human specific fecal contamination to coastal waters are often due to point source discharges of treated and untreated sewage, especially in the presence of combined wastewaterstormwater systems, while various nonpoint sources of general fecal contamination include terrestrial, agricultural, and stormwater runoff (Kay et al. 2008; Wyer et al. 2010). Increased watershed surface runoff and river discharges are linked to snowmelt and large precipitation events, leading to a seasonal effect of fecal pollution that can also be associated with increased coastal use in the summer months (Lipp et al. 2001; Tilburg et al. 2015). Additionally, fecal coliform abundance is correlated with increased human population, land development, and impervious coverage of a watershed (Mallin et al. 2000; Shehane et al. 2004).

Food safety concerns are also presented by Vibrio bacteria which naturally inhabit estuarine and coastal waters, and of which some species are human pathogens, including Vibrio parahaemolyticus which is an important bacterial cause of foodborne gastroenteritis in the USA. (Newton et al. 2012). This bacterium presents a well-known concern within the wild harvest or aquaculture of bivalves as it can bioaccumulate within their tissue in concentrations up to 100-fold higher than surrounding waters and is often responsible for bivalve harvest closures in areas similar to where macroalgae may be harvested (DePaola et al. 1990; Xu et al. 2015). Seasonal trends in Vibrio abundance are well-documented with concentrations increasing as water temperatures rise and are generally not detected during winter months (Maugeri et al. 2004; Turner et al. 2009). Rapid ocean warming has stimulated the growth of Vibrio within the North Atlantic, and consequently cases of infection are increasing within this region (Baker-Austin et al. 2013).

Research on bacterial pathogen contamination of sea vegetables is limited, particularly on species farmed in US waters. A few European studies failed to detect gastrointestinal pathogens on wild-collected macroalgae, including Laminaria (Liot et al. 1993; Moore et al. 2002; Gupta et al. 2010; Duinker et al. 2016), while Vibrio was detected on wild macroalgae in Japan (Mahmud et al. 2006, 2008). A recent study on S. latissima and Alaria esculenta farmed in Norway found no enterococci, coliforms, pathogenic Vibrio, or Listeria monocytogenes through plating methods (Blikra et al. 2019). To our knowledge, no studies have examined presence of bacterial pathogens on macroalgae harvested from the Northern Atlantic coast of the USA.

This study assesses the risk of bacterial contamination of sugar kelp $S$. latissima farmed for human consumption at nearshore aquaculture sites in ME, USA. Realtime PCR was utilized on kelp samples for sensitive and specific detection of the pathogens E. coli O157:H7, Salmonella enterica serovar Typhimurium, and V. parahaemolyticus on kelp samples, while plating methods similar to those employed by regulatory agencies for water testing were used for bacterial quantitation from kelp and source water. Findings from this study will be valuable for future development of food safety protocols to regulate and expand this region's sea vegetable industry.

\section{Materials and methods}

\section{Sampling sites}

Saco and Casco Bays are located on the southern coast of ME. They are parts of watersheds which serve some of the most populated areas of the state and are subject to various nonpoint and point anthropogenic or natural pollution sources. Samples were collected from two coastal sites of kelp aquaculture in Casco Bay (CB I and II), one being a commercial farm that supplies kelp to the food industry and the other being an educational lease for a local school, and another site in Saco Bay (SB) which was established for research purposes (Fig. 1). Kelp was grown on $200 \mathrm{~m}$ longlines suspended $2 \mathrm{~m}$ below the water surface (Flavin et al. 2013). Portions of Casco Bay and the majority of Saco Bay are closed to bivalve aquaculture for several reasons including proximity to wastewater treatment plant outfalls which indicate increased risk for bacterial pollution, actual elevated fecal coliform levels based on water sampling, and insufficient water quality data. Both bays are large however and there are several successful bivalve and kelp aquaculture farms located in the open areas of Casco Bay (ME DMR 2018a).

\section{Sample collection}

In the Northeast USA, kelp farms are seeded in October or November and grow throughout the winter until harvest at any time in March-May. Site CB I was sampled on 7 events during the typical growing season from February 6 to May 24, 
Fig. 1 Map of the Northeast USA with sampling region of ME marked by arrow. The close-up image shows 3 sites of kelp aquaculture in southern ME that were sampled during FebruaryMay 2018. In Casco Bay (CB; northern bay), site CB I is marked by the rhombus and CB II by the circle. These sites are approximately $2.5 \mathrm{~km}$ away from each other. In Saco Bay (SB; southern bay), site SB is marked by the square. SB is approximately $32 \mathrm{~km}$ south of the CB sites

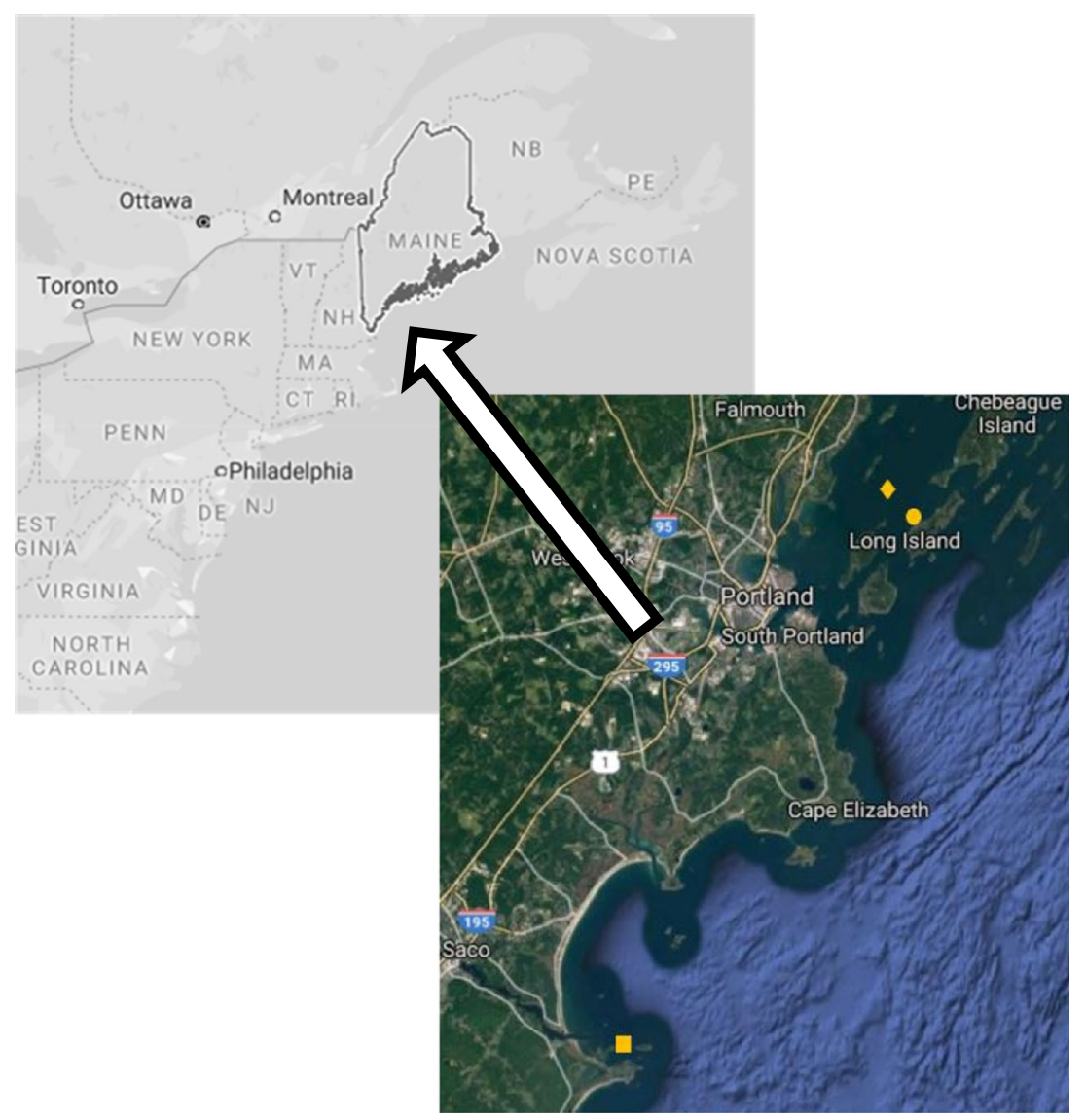

2018, while CB II was sampled a total of 4 times, corresponding with the sampling at CB I from April 23 to May 24, 2018. The SB site was sampled 9 times from February 22 to May 22, 2018. Frequency of sampling depended on weather conditions and was therefore limited prior to the end of March. During each sampling event, 2-4 blades of sugar kelp were taken from 2-4 areas on the longline. The longline was generally sampled at 4 points, except for at the CB II site where it was collected at 2-3 points due to a smaller biomass of kelp on the longline. At each point of kelp collection, $300 \mathrm{~mL}$ of surface water (SW) was collected using sterile Whirl-Pak bags and from $2 \mathrm{~m}$ depth (DW) using Niskin. All samples were collected using aseptic technique and placed on ice $\left(<2{ }^{\circ} \mathrm{C}\right)$ during the 30 min transport back to the lab where they were kept at temperature and processed within $3 \mathrm{~h}$ of return.

\section{Kelp processing and microbiological enrichment}

The kelp blades from each sampling replicate were cut horizontally along the blade into sections weighing approximately $2 \mathrm{~g}$ (fresh tissue weight). Any holdfast or fouled tissue was avoided as this would not be consumed by humans. The $2 \mathrm{~g}$ sections were compiled into five bunches each weighing $8 \mathrm{~g}$. Each $8 \mathrm{~g}$ kelp bunch was placed within a sterile Seward Stomacher bag with $100 \mathrm{~mL}$ of autoclaved, filtered $(0.35$ $\mu \mathrm{m})$ seawater, and stomached for 1 min using a Lab-Blender 80 (Tekmar) Stomacher to dislodge bacteria (Sharpe and Jackson 1972). After stomaching, the kelp tissue was discarded resulting in a $100 \mathrm{~mL}$ bacterial seawater suspension from each kelp sampling replicate. Two of these bacterial seawater suspensions were processed for real-time PCR analysis (qPCR) and 3 for membrane filtration and plating (see "Membrane filtration and plating" below).

For qPCR analysis, each stomached bacterial seawater suspension was aliquoted into $50-\mathrm{mL}$ volume and centrifuged at $5000 \mathrm{rpm}$ for $20 \mathrm{~min}$ to pellet bacterial cells. The 3 most compact pellets from each kelp replicate were chosen to avoid loss of sample when supernatants were discarded. Pellets were suspended in $3 \mathrm{~mL}$ of either universal pre-enrichment broth ((UPEB) Criterion-Hardy Diagnostics) for the enrichment of E. coli O157:H7 and $S$. Typhimurium, sterile alkaline peptone water ((APW) HiMedia Laboratories) for the enrichment of $V$. parahaemolyticus, or sterile phosphate-buffered saline (PBS) solution for preservation by freezing. UPEB- and APW-enriched samples were incubated at $37{ }^{\circ} \mathrm{C}$ for $18 \mathrm{~h}$. Following enrichment, each solution was frozen at $-80^{\circ} \mathrm{C}$ until DNA extraction. The samples in PBS were frozen immediately after resuspension to preserve for further analysis if required. To control for potential background amplification resulting from environmental contamination of media, media-only controls 
consisting of sterile APW, UPEB, or FSW were incubated at 37 ${ }^{\circ} \mathrm{C}$ for $18 \mathrm{~h}$ and then subjected to DNA isolation and qPCR analysis. If background amplification was detected, baseline $\mathrm{C}_{t}$ values used for determination of positive detection in test samples were adjusted accordingly. While the enrichment step aids in detection of microbes present in low numbers by supporting microbial resuscitation and growth, it should be noted that this prevents bacterial quantitation. qPCR methods were therefore used for highly effective presence/absence detection of bacterial pathogens, and results were operationally similar to those from traditional PCR. The use of qPCR on enriched samples was chosen over traditional PCR because of its increased sensitivity for detecting microbes that are present in low abundances (Postollec et al. 2011).

\section{DNA extraction and qPCR analysis}

Bacterial DNA was isolated from each enriched sample using the DNeasy Blood and Tissue Kit (Qiagen) according to manufacturer's protocol. DNA extracts were purified using the DNeasy PowerClean Pro Cleanup Kit (Qiagen) according to manufacturer's protocol to remove potential seaweedassociated inhibitors that might interfere with downstream amplification.

A StepOnePlus Real-Time PCR (qPCR) system (Applied Biosystems by Thermo Fisher Scientific) was used for target DNA amplification and robust detection of PCR products. qPCR reactions were single-plex with SYBR green detection chemistry, using PowerUP SYBR green Master Mix (Applied Biosystems by Thermo Fisher Scientific), and forward and reverse primers specific to pathogen: eaeA-F (ATGCTTAG TGCTGGTTTAGG) and eaeA-R (GCCTTCATCATTTC GCTTTC) for E. coli O157:H7 (Fukushima et al. 2003); iroB-F (ATACGCCCTGGCACATCAAA) and iroB-R (AACCGGCTCTCCGTCATTTT; Bäumler et al. 1997; this study); trh-F (GGCTCAAAATGGTTAAGCG) and trh-R (CATTTCCGCTCTCATATGC; Fukushima et al. 2003). The amplification program was as follows: $50{ }^{\circ} \mathrm{C}$ for $2 \mathrm{~min}, 95^{\circ} \mathrm{C}$ for $2 \mathrm{~min}$, and 45 cycles of $95^{\circ} \mathrm{C}$ for $15 \mathrm{~s}$, annealing temperature specific to primer for $15 \mathrm{~s}\left(47^{\circ} \mathrm{C}, 55^{\circ} \mathrm{C}, 55^{\circ} \mathrm{C}\right.$, respectively), and $72{ }^{\circ} \mathrm{C}$ for $1 \mathrm{~min}$, followed with a melt curve of 95 ${ }^{\circ} \mathrm{C}, 60{ }^{\circ} \mathrm{C}$, and $95{ }^{\circ} \mathrm{C}$. Standard curves were not used for quantitation due to sample enrichment. Genomic DNA isolated from pure cultures of $V$. parahaemolyticus, E. coli O157:H7, and S. enterica ser. Typhimurium were run as positive controls.

\section{Membrane filtration and plating}

The remaining three stomached bacterial seawater suspensions from each kelp replicate were vacuum-filtered in 50 - and $100-\mathrm{mL}$ volumes onto $0.2 \mu \mathrm{m}$ gridded membrane filters (Whatman). Filters were placed in $50-\mathrm{mm}$ petri dishes with either m-TEC media (Neogen Acumedia) to enumerate coliforms (Dufour et al. 1981) or TCBS media (Neogen Acumedia) to enumerate Vibrio species (Kobayashi et al. 1963). The SW and DW samples were similarly processed. All plates were incubated at $37{ }^{\circ} \mathrm{C}$ for $24 \mathrm{~h}$ and then counted. As per manufacturer's instructions for the m-TEC media, absorbent pads soaked with $2 \mathrm{~mL}$ of urea substrate made with $2 \mathrm{~g}$ urea and $10 \mathrm{mg}$ phenol red (Sigma Aldrich) in $100 \mathrm{~mL}$ water were added to the new 50-mm petri dishes, and the membrane filters from the original petri dishes were transferred to sit on top of the pads. After $20 \mathrm{~min}$, all yellow and yellow-green to yellow-brown colonies were counted as urease-negative, thermotolerant E. coli. For the TCBS media, green colonies were counted as presumptive $V$. parahaemolyticus and yellow colonies as presumptive Vibrio alginolyticus, according to manufacturer's protocol. Plating data are presented as colony forming units (cfu) per $100 \mathrm{~mL}$ and generally represent the counts from the $100 \mathrm{~mL}$ filter volume plates. In the case of the $100 \mathrm{~mL}$ plates having growth too numerous to count, the counts from the $50-\mathrm{mL}$ filter volumes were calculated to cfu per $\mathrm{mL}$. These plating procedures were used in order to remain consistent with current state of $\mathrm{ME}$ water quality monitoring procedures for bivalve aquaculture (ME DMR 2018a).

\section{Data analysis}

qPCR methodology increased sensitivity and specific detection of the pathogenic species, however data is presented as presence/absence due to the demonstrated need for microbiological enrichment which prevented quantitation (Online Resource A). A sampling event was marked positive for the pathogen if the pathogen DNA was detected in at least one sampling replicate. Plate count data were not normal and could not effectively be transformed. Nonparametric Kruskal-Wallis tests were run for each bacterial group ( $V$. parahaemolyticus, $V$. alginolyticus, and $E$. coli) to test for significance of sampling site (SB, CB I, CB II) and for significance of sample type (kelp, SW, DW). If statistical significance was found, Dunn multiple comparisons were run post hoc. Additionally, a general linear mixed effects model with a negative binomial distribution for each bacterial group was utilized to test significance of sample type with sampling site and date incorporated as crossed random factors. Estimated marginal means tests were used for post hoc analysis. All statistical analyses were performed with the $\mathrm{R}$ version 3.5.2. Environmental data were not collected in great enough quantities to perform detailed statistical analyses and were therefore used for solely qualitative interpretations. 


\section{Results}

\section{Pathogen detection through qPCR}

A preliminary study revealed that qPCR-mediated detection of pathogens on kelp was enhanced when samples were subjected to a microbiological enrichment step. Therefore, kelp samples were enriched prior to DNA isolation, which enabled us to detect (but not quantitate) the presence of specific pathogens. The qPCR methods used were effective in detecting all target pathogens on kelp throughout the duration of sampling. Salmonella Typhimurium was detected most frequently on samples from $83 \%$ of the 18 sampling events (Table 1). This bacterium was detected on all the events at both $\mathrm{CB}$ sites, and it was present on just over half of the events at SB but its presence did not appear to follow a temporal trend (Table 2). Of 50 kelp samples collected throughout the season, $60 \%$ were positive for $S$. Typhimurium. Vibrio parahaemolyticus was also frequently detected, during $78 \%$ of all sampling events. Vibrio parahaemolyticus was detected in $52 \%$ of all sampling replicates throughout the season and was present at all sites with no temporal pattern. Escherichia coli O157:H7 was detected on $56 \%$ of all sampling events, in greatest frequency at the CB I site. Of all sampling replicates, E. coli O157:H7 was present in 46\% of them. In contrast to the other pathogens, E. coli O157:H7 was not present at CB II and SB in May. It was rare for the pathogen of interest to be detected in all sampling replicates per sampling event. All 3 replicates of the sampling event were positive for $V$. parahaemolyticus on 3 events, compared with on just 2 events for $S$. Typhimurium and 1 for $E$. coli O157:H7. This could infer that

Table 1 Percent of sampling events ( $n=8$ (SB), 6 (CB I), 4 (CB II); total $n=18$ ) and kelp sampling replicates $(n=24$ (SB), 17 (CB I), 9 (CB II); total $n=50$ ) in which each pathogen was detected through qPCR methods

\begin{tabular}{llll}
\hline Pathogen & Site & $\begin{array}{l}\text { Events positive } \\
\text { for each } \\
\text { pathogen (\%) }\end{array}$ & $\begin{array}{l}\text { Replicates positive } \\
\text { for each } \\
\text { pathogen (\%) }\end{array}$ \\
\hline E. coli O157:H7 & SB & 50 & 29 \\
& CB I & 83 & 86 \\
& CB II & 25 & 22 \\
S. enterica ser. & All & 56 & 46 \\
Typhimurium & SB & 56 & 25 \\
& CB I & 100 & 65 \\
& CB II & 100 & 89 \\
V. parahaemolyticus & All & 83 & 60 \\
& SB & 88 & 50 \\
& CB I & 67 & 41 \\
& CB II & 75 & 78 \\
& All & 78 & 52 \\
\hline
\end{tabular}

Table 2 Proportion of samples determined positive through qPCR methods for each pathogen per sampling event and per site. Samples taken in triplicates on all events except for $4 / 29,5 / 16$, and 5/24 at site C and $5 / 24$ at site $B$

\begin{tabular}{|c|c|c|c|c|}
\hline $\begin{array}{l}\text { Sampling } \\
\text { event }\end{array}$ & Site & $\begin{array}{l}\text { Proportion } \\
\text { samples } \\
\text { positive } \\
\text { for } E \text {. coli } \\
\text { O157:H7 }\end{array}$ & $\begin{array}{l}\text { Proportion } \\
\text { samples } \\
\text { positive for } S . \\
\text { Typhimurium }\end{array}$ & $\begin{array}{l}\text { Proportion } \\
\text { samples positive } \\
\text { for } \\
\text { V. parahaemolyticus }\end{array}$ \\
\hline Mar 20 & SB & $1 / 3$ & $1 / 3$ & $2 / 3$ \\
\hline Mar 20 & CB I & $1 / 3$ & $3 / 3$ & $2 / 3$ \\
\hline Apr 4 & CB I & $1 / 3$ & $1 / 3$ & $0 / 3$ \\
\hline Apr 11 & SB & $1 / 3$ & $2 / 3$ & $3 / 3$ \\
\hline Apr 19 & SB & $3 / 3$ & $1 / 3$ & $2 / 3$ \\
\hline Apr 23 & SB & $2 / 3$ & $0 / 3$ & $1 / 3$ \\
\hline Apr 23 & CB I & $1 / 3$ & $2 / 3$ & $3 / 3$ \\
\hline Apr 23 & $\begin{array}{c}\text { CB } \\
\text { II }\end{array}$ & $2 / 3$ & $3 / 3$ & $3 / 3$ \\
\hline Apr 29 & CB I & $1 / 3$ & $2 / 3$ & $1 / 3$ \\
\hline Apr 29 & $\begin{array}{c}\text { CB } \\
\text { II }\end{array}$ & $0 / 2$ & $2 / 2$ & $0 / 2$ \\
\hline May 1 & SB & $0 / 3$ & $1 / 3$ & $2 / 3$ \\
\hline May 8 & SB & $0 / 3$ & $0 / 3$ & $0 / 3$ \\
\hline May 16 & CB I & $0 / 3$ & $2 / 3$ & $1 / 3$ \\
\hline May 16 & $\begin{array}{l}\mathrm{CB} \\
\text { II }\end{array}$ & $0 / 2$ & $1 / 2$ & $2 / 2$ \\
\hline May 17 & SB & $0 / 3$ & $1 / 3$ & $1 / 3$ \\
\hline May 22 & SB & $0 / 3$ & $0 / 3$ & $1 / 3$ \\
\hline May 24 & CB I & $2 / 2$ & $1 / 2$ & $0 / 2$ \\
\hline May 24 & $\begin{array}{c}\mathrm{CB} \\
\text { II }\end{array}$ & $0 / 2$ & $2 / 2$ & $2 / 2$ \\
\hline
\end{tabular}

there was a greater number of target bacterial cells present prior to enrichment during these sampling events.

\section{Pathogen detection through plating}

\section{E. coli}

On kelp, plating detection of $E$. coli from all sampling events averaged $4 \pm 2 \mathrm{cfu} / 100 \mathrm{~mL}$ (mean \pm standard error; Fig. 2), specifically $4 \pm 2 \mathrm{cfu} / 100 \mathrm{~mL}$ at CB I, $11 \pm 6 \mathrm{cfu} / 100 \mathrm{~mL}$ at $\mathrm{CB}$ II, and $1 \pm<1 \mathrm{cfu} / 100 \mathrm{~mL}$ at SB (Fig. 3). Throughout the season, E. coli abundance on kelp was generally low ( $0-4 \mathrm{cfu} /$ $100 \mathrm{~mL}$; Fig. 4) and not consistent as just $55 \%$ of sampling events $(n=20)$ had detection (Table 3$)$. There was a prominent E. coli presence $(34 \pm 20 \mathrm{cfu} / 100 \mathrm{~mL})$ on April 23 at CB II. Concentrations reached $10-13 \mathrm{cfu} / 100 \mathrm{~mL}$ on 2 other events, however on the other 7 sampling events with detection on kelp, levels did not exceed $8 \mathrm{cfu} / 100 \mathrm{~mL}$. In SW, E. coli was detected on $65 \%$ of sampling events, but the mean concentration from all sampling events was still low at $2 \pm 1 \mathrm{cfu} / 100 \mathrm{~mL}$. Escherichia coli was present in water at DW the most frequently, during $80 \%$ 
Fig. 2 Mean concentrations (cfu/ $100 \mathrm{~mL}$ ) of V. parahaemolyticus, $V$. alginolyticus, and E. coli determined through plating from surface water (SW), water at $2 \mathrm{~m}$ below surface (DW), and kelp (K) from all sampling events from February-May 2018 at all sites (CB I, CB II, SB). Error bars represent standard error

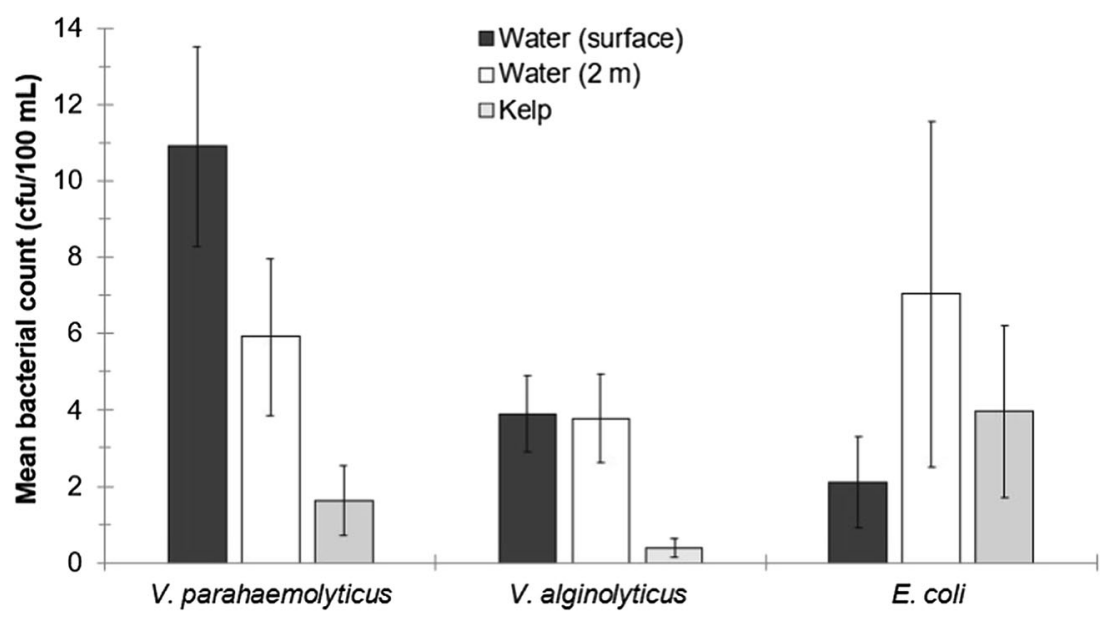

of sampling events, and in the largest abundance, averaging $7 \pm 5$ $\mathrm{cfu} / 100 \mathrm{~mL}$ for all events. The maximum $E$. coli concentration recorded was $97 \pm 70 \mathrm{cfu} / 100 \mathrm{~mL}$ in DW on April 19 (SB), contrasting with all other detections in both water sample types which ranged from $0-13 \mathrm{cfu} / 100 \mathrm{~mL}$. Bacterial concentrations did not significantly differ between water collected from the surface and at $2 \mathrm{~m}$ (Kruskal-Wallis $p$ value $>0.05$ ).

Sample type (SW, DW, kelp) had no significant effect on E. coli concentration, determined by both statistical models (Kruskal-Wallis $p$ value $>0.05$; negative binomial generalized linear mixed-effects model (NB GLM-E) $p$ value $>0.05$ ). Escherichia coli detection in both water types was similar to that on kelp, all in low concentrations of 0-12 cfu/100 mL except for the noted spikes. Furthermore, the mean count of $E$. coli from all sampling events on kelp was just $2 \mathrm{cfu} / 100 \mathrm{~mL}$ greater than $\mathrm{SW}$ and $2 \mathrm{cfu} / 100 \mathrm{~mL}$ less than DW. Notably, the maximum E. coli detection in DW (April 19, SB) was paired with minimal detection on kelp. In contrast, there was little detection in water when E. coli levels were strikingly high on kelp (April 23, CB II). Both spikes were paired with zero detection in SW.

Bacterial concentrations per sampling event in any sample type did not vary significantly between sampling sites (Kruskal-Wallis $p$ values $>0.05$ ). There was an apparent difference in frequency as $E$. coli was detected on kelp on $22 \%$ of the sampling events $(n=9)$ at the SB site, in contrast to $67 \%$ at CB I $(n=7)$ and $75 \%$ at CB II $(n=4)$. The overall mean concentration was relatively larger in DW at SB and on kelp at CB II compared with other sites. Bacterial concentrations in any sample type did not vary significantly between sampling dates (Kruskal-Wallis $p$ value $>0.05$ ). Escherichia coli was not frequently detected until mid-April, but concentrations stayed relatively constant after this point.

\section{V. parahaemolyticus}

Vibrio parahaemolyticus was detected on kelp from $83 \%$ of the sampling events (Table 3). Bacterial concentrations per sampling event ranged from $0-8 \mathrm{cfu} / 100 \mathrm{~mL}$, averaging $1 \pm$
$1 \mathrm{cfu} / 100 \mathrm{~mL}$ from all SB events, $1 \pm 1 \mathrm{cfu} / 100 \mathrm{~mL}$ for CB I, and $3 \pm 2 \mathrm{cfu} / 100 \mathrm{~mL}$ for CB II (Figs. 3, 5). The overall concentration of $V$. parahaemolyticus on kelp was $2 \pm 1 \mathrm{cfu} /$ $100 \mathrm{~mL}$, while $55 \%$ of sampling events had detection of just 0-1 cfu/100 mL. In SW, V. parahaemolyticus was detected on all but one event, while it was present during $75 \%$ of sampling events in DW. The overall mean concentrations from all sampling events equaled $11 \pm 3 \mathrm{cfu} / 100 \mathrm{~mL}$ in $\mathrm{SW}$ and $6 \pm 2 \mathrm{cfu} / 100 \mathrm{~mL}$ in DW. Bacterial concentrations peaked on April 19 in SW $(151 \pm 16 \mathrm{cfu} / 100 \mathrm{~mL})$ and DW $(76 \pm 20 \mathrm{cfu} / 100 \mathrm{~mL})$ at SB. Apart from this event, the sampling event concentrations ranged from 0-18 cfu/100 mL, though abundance was often lower as 15 of 20 sampling events for SW and 11 for DW had detection between 0 and $4 \mathrm{cfu} / 100 \mathrm{~mL}$. Bacterial concentrations did not significantly differ between SW and DW (Kruskal-Wallis $p$ value $>0.05$ ).

According to Kruskal-Wallis analysis, sample type did not significantly affect $V$. parahaemolyticus concentrations ( $p$ values $>0.05$ ). However, a significant effect of sample type was determined by the NB GLM-E utilized to account for possible influence of sampling times (date) and sites. Vibrio parahaemolyticus concentrations on kelp were significantly lower than in SW (estimated marginal means $(\mathrm{EMM}) p$ value $\left.=1.00 \times 10^{-4}\right)$ and DW $($ EMM $p$ value $=4.13 \times 10^{-2}$ ). Mean $V$. parahaemolyticus counts on kelp from all sampling events were lower by $9 \mathrm{cfu} / 100$ $\mathrm{mL}$ compared with $\mathrm{SW}$ and $4 \mathrm{cfu} / 100 \mathrm{~mL}$ compared with DW. Vibrio parahaemolyticus was absent on kelp but present in SW on 4 of 20 sampling events, 3 of which was also detected in DW. Abundance was lower in kelp compared with water samples during more than half (12 of 20) of sampling events for each water type. Three spikes seen in $V$. parahaemolyticus detection in water were paired with zero detection (February 22, SB; May 22, SB) or minimal detection (April 19, SB) on the paired kelp samples. Vibrio parahaemolyticus was detected on kelp but not in either water type on only one event (March 20, SB). 
a

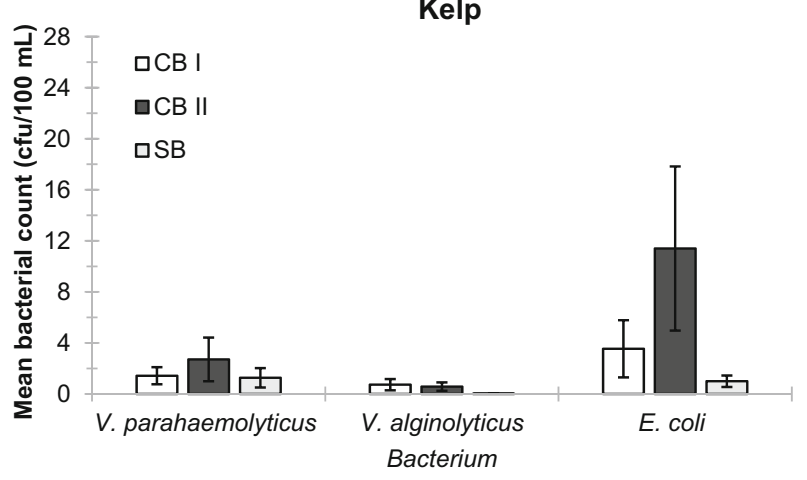

b

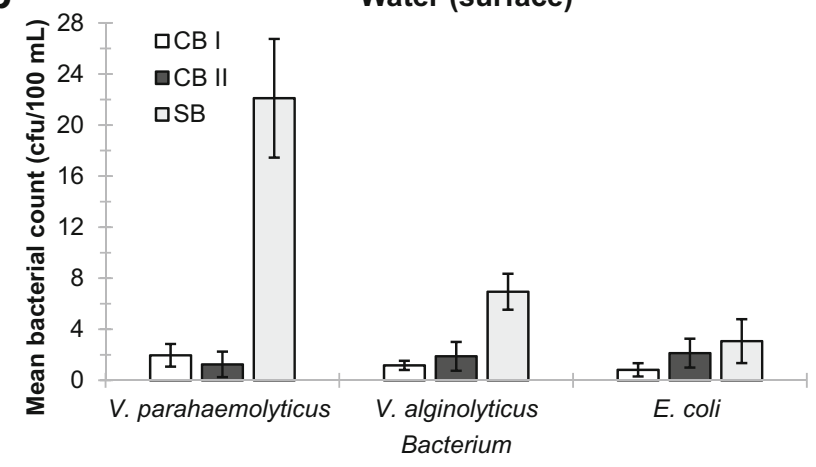

C

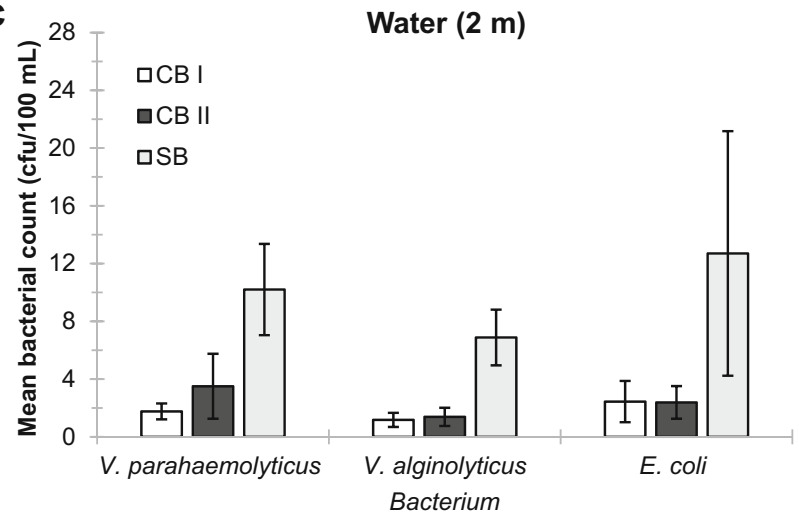

Fig. 3 Mean concentrations (cfu/100 mL) of V. parahaemolyticus, $V$. alginolyticus, and E. coli determined through plating from (a) kelp, (b) surface water, and (c) water at $2 \mathrm{~m}$ below surface sampled at the 3 sites during February-May 2018. Data are means of plate counts from all sampling events at Casco Bay site I (CB I; $n=7$ events) and site II (CB II, $n=4)$ and the Saco Bay site (SB; $n=9$ ). Error bars represent standard error

The mean concentration of $V$. parahaemolyticus detected in SW from all SB sampling events $(22 \pm 5 \mathrm{cfu} / 100 \mathrm{~mL})$ was much greater than at CB I $(2 \pm 1 \mathrm{cfu} / 100 \mathrm{~mL})$ and CB II $(1 \pm 1$ $\mathrm{cfu} / 100 \mathrm{~mL})$. Its frequency of detection at SB (78\%) was also relatively larger than at CB I (57\%) and CB II (50\%). No other distinct spatial or temporal trends in V. parahaemolyticus concentrations were distinguishable. Furthermore, site and date were not found to have significant effects on bacterial abundance (Kruskal-Wallis $p$ values $>0.05$ ).

\section{V. alginolyticus}

Abundance of $V$. alginolyticus on kelp was minimal as the mean bacterial concentration of all sampling events was 0.4 $\pm<1 \mathrm{cfu} / 100 \mathrm{~mL}$ (Fig. 2), and this bacterium was detected on just one third (37\%) of sampling events (Table 3), all at concentrations below $4 \mathrm{cfu} / 100 \mathrm{~mL}$ (Fig. 6). Vibrio alginolyticus was detected on $65 \%$ of sampling events in SW and $75 \%$ in DW. The abundance of $V$. alginolyticus was similar in both water types, averaging $4 \pm 1 \mathrm{cfu} / 100 \mathrm{~mL}$ (SW) and $4 \pm 1 \mathrm{cfu} /$ $100 \mathrm{~mL}$ (DW) across all sampling events. Bacterial concentrations peaked in SW on May $1(16 \pm 1 \mathrm{cfu} / 100 \mathrm{~mL})$ and May $17(30 \pm 8 \mathrm{cfu} / 100 \mathrm{~mL})$ and in DW on April $19(20 \pm 6$ $\mathrm{cfu} / 100 \mathrm{~mL})$ and May $17(24 \pm 2 \mathrm{cfu} / 100 \mathrm{~mL})$, all at SB. The mean concentrations of $V$. alginolyticus in the remainder of the water samples per sampling event ranged from $0-9 \mathrm{cfu} / 100$ $\mathrm{mL}$ with means of $0-4 \mathrm{cfu} / 100 \mathrm{~mL}$ on $13(\mathrm{SW})$ and 18 (DW) of the 20 sampling events.

Sample type had a significant effect on bacterial concentration (Kruskal-Wallis $p=3.43 \times 10^{-3}$ ). Vibrio alginolyticus counts per sampling event were significantly greater in SW than on kelp (Dunn post hoc $p$-adj $=1.77 \times 10^{-2}$ ) and in water at $2 \mathrm{~m}$ compared with kelp (Dunn, $p$-adj $=4.17 \times 10^{-3}$ ). Furthermore, according to the NB GLM-E, the abundance of $V$. parahaemolyticus in SW and DW was greater than on kelp $\left(\right.$ EMM $p$ values $=1.00 \times 10^{-4}$ for both $)$. Overall, mean $V$. alginolyticus counts in both water types were $3 \mathrm{cfu} / 100$ $\mathrm{mL}$ greater than on kelp. Vibrio alginolyticus was absent on kelp while present in SW on 9 of 20 events and present in DW on 11. The maximum concentrations in water previously noted were all associated with zero detection on kelp on the paired date. The maximum detections on kelp occurred when there was little detection in both water types.

The mean concentration of $V$. alginolyticus detected in SW from all SB sampling events $(7 \pm 1 \mathrm{cfu} / 100 \mathrm{~mL})$ was higher than at CB I $(1 \pm<1 \mathrm{cfu} / 100 \mathrm{~mL})$ and CB II $(1.9 \pm 1 \mathrm{cfu} / 100$ $\mathrm{mL})$. This trend was similar with DW as concentrations were 7 $\pm 2 \mathrm{cfu} / 100 \mathrm{~mL}, 1 \pm<0 \mathrm{cfu} / 100 \mathrm{~mL}$, and $1 \pm<0 \mathrm{cfu} / 100 \mathrm{~mL}$ for SB, CB I, and CB II, respectively. This variation was not significant as site did not significantly influence $V$. alginolyticus concentration (Kruskal-Wallis, $p$ value $>$ 0.05 ). In water, a weak trend of increasing $V$. alginolyticus abundance as the season progressed was seen, however date did not have a significant effect on bacterial concentration (Kruskal-Wallis, $p$ value $>0.05$ ).

\section{Discussion}

\section{Kelp food safety}

This study reports qPCR-mediated detection of enterohemorrhagic E. coli O157:H7, S. Typhimurium, and 
Fig. 4 Effect of date, site, and sample type on $E$. coli concentration (cfu/100 mL). Surface water, water at $2 \mathrm{~m}$ below surface, and kelp sampled at kelp aquaculture sites in Saco Bay (SB $=\mathrm{A})$ and Casco Bay $(\mathrm{CB} \mathrm{I}=\mathrm{B}$, $\mathrm{CB}$ II $=\mathrm{C}$ ) in 2018. Top and bottom figures are identical except for the cropped $y$-axis on the bottom. Data are means of $\mathrm{m}$ TEC plate counts $(n=3-4(\mathrm{SB})$, 2-4 (CB I), 2 (CB II) per sampling event for each sample type. Error bars represent standard error

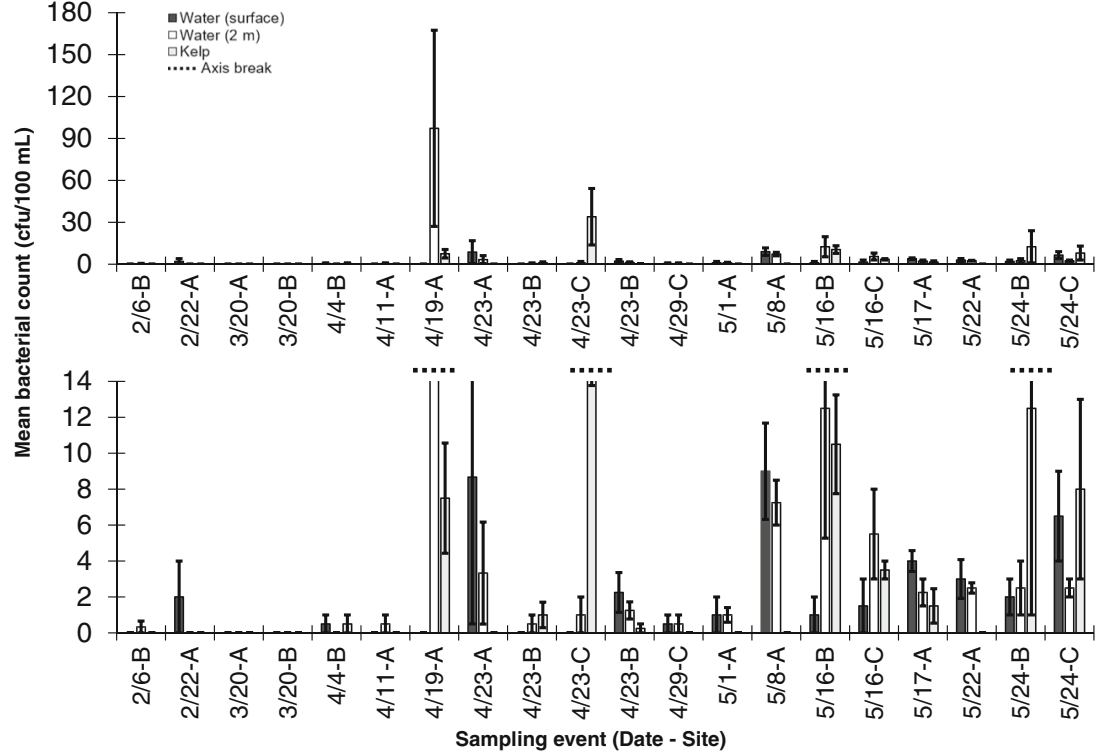

V. parahaemolyticus for the first time on fresh sugar kelp farmed in the Northeast USA. Within this region, the presence of fecal bacteria and Vibrio in coastal waters are expected, but knowledge of their associations with macroalgal surfaces is relatively undocumented (Weiskel et al. 1996; Brands et al. 2005; Urquhart et al. 2016). It was common for at least two of these pathogens to be present per sampling event during the winter growing season. This frequent detection validates the concern that these bacterial pathogens may persist in growing waters and associate with kelp tissue. The presence of these pathogens was detected after enrichment which made it impossible to quantitate the initial bacterial load, but low bacterial quantities may still present food safety concerns. The infectious dose for these pathogens varies by strain and physiological condition of the host but may be as low as fewer than 1000 cells (Blaser and Newman 1982; Su and Liu 2007). Low infectious doses and rapid growth rates suggest the need for regulatory guidelines to control microbial growth during post- harvest storage, transport, and processing (Labbé and Garcia 2013). Freshly harvested kelp may be exposed to direct sun if precautions are not taken, or drying processes may introduce temperature and humidity conditions optimal for bacterial growth (Bourdoux et al. 2016). In addition, potentially toxic spore-forming Bacillus spp. have been isolated from kelps and are concerning as they can survive thermal processing (Gupta et al. 2010; Blikra et al. 2019).

The frequent detection of E. coli $\mathrm{O} 157: \mathrm{H} 7$ and $S$. Typhimurium presence on kelp samples through qPCR is substantiated by the continuous detection of $E$. coli in water samples through plating. Mean E. coli plate counts per sampling event generally did not exceed $12 \mathrm{cfu} / 100 \mathrm{~mL}$. As a reference for this level of fecal indicator detection, state of ME regulations prohibit bivalve harvest in waters where routine sampling determines that the median geometric mean exceeds $14 \mathrm{cfu} / 100$ $\mathrm{mL}$ (NSSP 2017). This threshold was met on only one sampling event when the geometric mean was $23 \mathrm{cfu} / 100 \mathrm{~mL}$ in
Table 3 Percent of sampling events $(n=9$ (SB), 7 (CB I), 4 (CB II); total $n=20$ ) positive for each bacterium determined through plating methods. Sampling event counted as positive when target bacterium grew on at least one plate $(n=3-4$ (SB), 2-4 (CB I), 2 (CB II) plates per sampling event)

\begin{tabular}{lllll}
\hline Bacterium & Site & Kelp (\%) & Water (surface, \%) & Water (2 m, \%) \\
\hline E. coli & SB & 22 & 67 & 78 \\
& CB I & 67 & 57 & 71 \\
& CB II & 75 & 75 & 100 \\
V. parahaemolyticus & All & 55 & 65 & 80 \\
& SB & 67 & 89 & 89 \\
& CB I & 83 & 100 & 57 \\
V. alginolyticus & CB II & 100 & 100 & 75 \\
& All & 83 & 95 & 75 \\
& SB & 11 & 78 & 78 \\
& CB I & 50 & 57 & 71 \\
& CB II & 50 & 50 & 800 \\
\hline
\end{tabular}


Fig. 5 Effect of date, site, and sample type on

V. parahaemolyticus concentration (cfu/100 mL). Surface water, water at $2 \mathrm{~m}$ below surface, and kelp sampled at kelp aquaculture sites in Saco Bay (SB $=\mathrm{A})$ and Casco Bay $(\mathrm{CB} \mathrm{I}=\mathrm{B}$, $\mathrm{CB}$ II $=\mathrm{C}$ ) in 2018. Top and bottom figures are identical except for the cropped $y$-axis on the bottom. Data are means of TCBS plate counts $(n=3-4$ (SB), 2-4 (CB I), 2 (CB II) per sampling event for each sample type. Error bars represent standard error

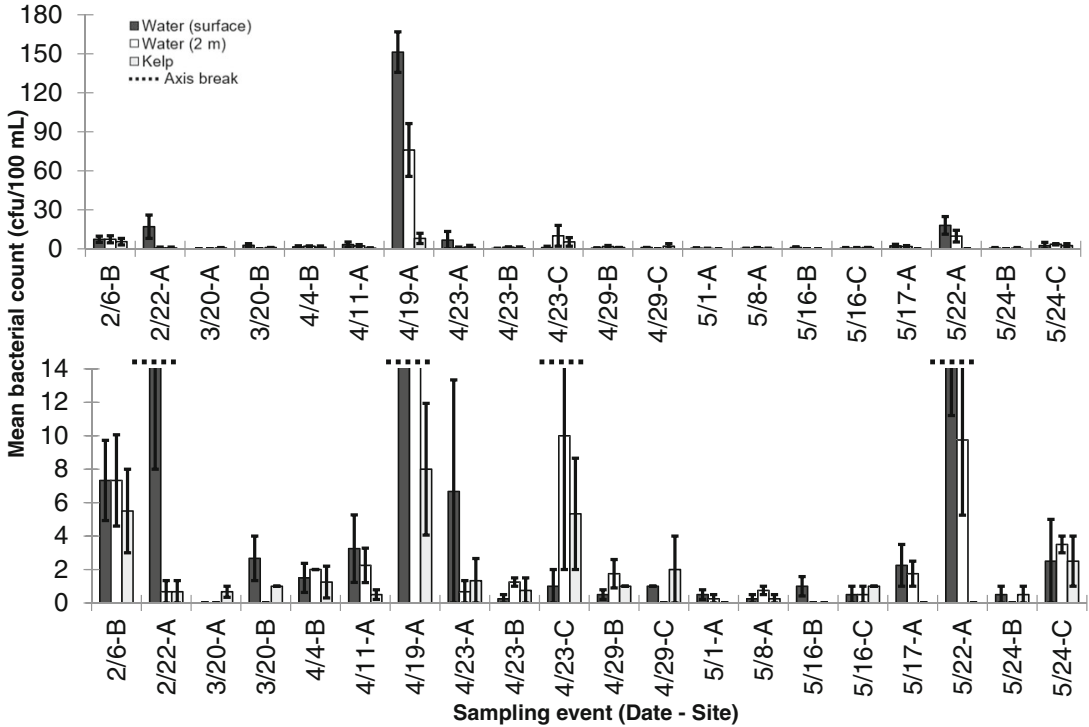

DW (reported arithmetic mean of $97 \mathrm{cfu} / 100 \mathrm{~mL}$ ). This threshold accounts for the bioaccumulation within shellfish tissue of the bacteria contained in water that they filter feed, but this study showed no accumulation of $E$. coli on kelp compared with that of in water. Through a recent produce safety rule, the FDA requires agricultural water that is directly applied to growing produce to hold less than $126 \mathrm{cfu} / 100 \mathrm{~mL}$ E. coli per $100 \mathrm{~mL}$ sample (U.S. FDA 2019), a much higher threshold that may be more relatable to sea vegetables. qPCR analysis of kelp allowed for more sensitive and specific detection of $E$. coli O157:H7 and led to its identification on 5 sampling events when general $E$. coli was not present on plates.

As a natural inhabitant of coastal waters, the presence of Vibrio on macroalgae has been reported but not in aquaculture settings (Duan et al. 1995; Vugia et al. 1997; Wang et al. 2008). Plating techniques found $V$. parahaemolyticus to be present in very low concentrations on kelp, not exceeding $1 \mathrm{cfu} / 100 \mathrm{~mL}$ on half of the sampling events. Colonies enumerated on TCBS media can only be identified presumptively without molecular identification (Bisha et al. 2012), but there were just 2 sampling events when $V$. parahaemolyticus was detected on kelp through plating and not through qPCR. Environmental studies often report virulence within only a proportion of the $V$. parahaemolyticus population as some strains are not pathogenic (Parveen et al. 2008; Rodriguez-Castro et al. 2010) and therefore plating may overestimate risk of pathogenicity. However, V. parahaemolyticus virulence gene trh was consistently amplified via qPCR, which confirmed presence of virulent strains in many kelp samples. Since pathogenic $V$. parahaemolyticus strains may possess a variety of virulence factors, our future work will include primers for additional virulence genes (Letchumanan et al. 2014).
Fig. 6 Effect of date, site, and sample type on $V$. alginolyticus concentration (cfu/100 mL) Surface water, water at $2 \mathrm{~m}$ below surface, and kelp sampled at kelp aquaculture sites in Saco Bay (SB $=\mathrm{A})$ and Casco Bay $(\mathrm{CB} \mathrm{I}=\mathrm{B}$, CB II = C) in 2018. Top and bottom figures are identical except for the cropped $y$-axis on the bottom. Data are means of TCBS plate counts $(n=3-4$ (SB), 2-4 (CB I), 2 (CB II) per sampling event for each sample type. Error bars represent standard error

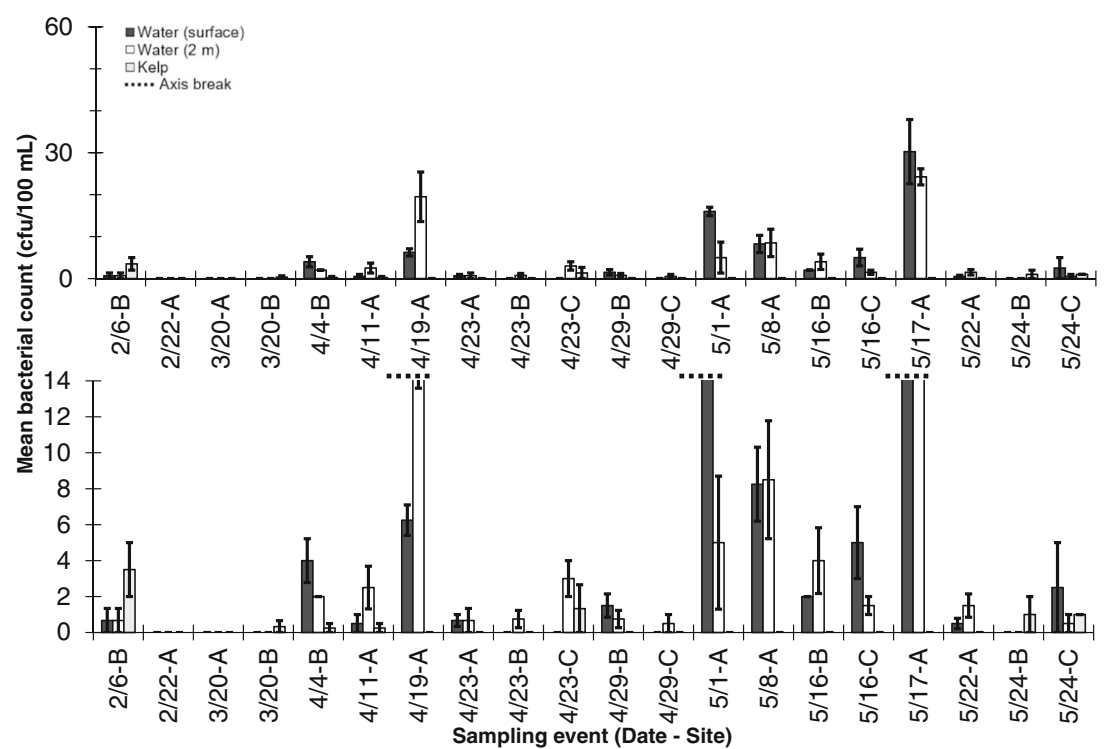


This study detected V. parahaemolyticus and V. alginolyticus throughout the winter sampling when water temperature remained below $10^{\circ} \mathrm{C}$ (Online Resource B) which was somewhat unexpected as $V$. parahaemolyticus detection in this region is generally reported from May-October (Watkins and Cabelli 1985; Jones and Summer-Brason 1998; Tantillo et al. 2004; Urquhart et al. 2016). These findings indicate that Vibrio contamination during the winter-spring kelp growing season is possible and should not be overlooked due to low environmental temperatures. However, PCR methods may detect pathogens in a viable but non-culturable (VBNC) state due to low environmental temperature (Hassard et al. 2017). Bacteria in VBNC are expected to maintain virulence and be pathogenic upon resuscitation (Oliver 2005) or in the case of macroalgal aquaculture, processing, and should therefore still be considered in food safety risk assessments. As sea surface temperatures within the Gulf of Maine warm, the likelihood of V. parahaemolyticus presence may become an increasing threat, as the duration of its preferred water temperature lengthens (Mahoney et al. 2010; Thomas et al. 2017).

\section{Kelp-seawater relationship}

Ecological studies have reported bacterial phylotypes on naturally growing kelp to be different than those in the surrounding seawater, differences which are often attributed to antimicrobial properties connected with the macroalga (Staufenberger et al. 2008; Lachnit et al. 2011, 2013; Michelou et al. 2013). This study suggests that $E$. coli from the water column associates with kelp tissue since plate counts on kelp and water were similar on most sampling events, although exceptions were noted. However, the maximum plating detection in water was paired with a low abundance on kelp, and there were several events when E. coli was detected in water and not on the kelp samples. Interestingly, members of kelp bacterial communities have shown activity against E. coli (Boyd et al. 1999; Wiese et al. 2009), and activities against E. coli and Salmonella were observed from kelp extracts (Cox et al. 2010; Meillisa et al. 2013). In contrast to E. coli, V. parahaemolyticus and V. alginolyticus were significantly more abundant in both water types than on kelp, suggesting that if Vibrio is present in the water column, it may not be attached to kelp. Extracts from the kelp Laminaria digitata have previously been shown to inhibit the growth of Vibrio species (Dubber and Harder 2008). It is notable that the greatest amount of $V$. alginolyticus detected on kelp corresponded with some of the lowest detections in both water sample types, suggesting that $V$. alginolyticus may stay associated with kelp longer than it persists in water. Determining the degree to which antibacterial properties of kelp are related to the differences in bacterial concentrations on kelp and water reported in this study requires more intensive research.
Currently applied phycological research focuses on identifying bioactive compounds for antibiotic use with fish and shrimp aquaculture species (Vatsos and Rebours 2015), but these properties may also be applicable to macroalgal culture (Wang et al. 2019). Further research into the microbiomes of macroalgae grown for food may provide insights to further understand how algal antibacterial properties could affect the association of these pathogenic bacteria from the water column, noting natural variations in bacterial communities due to geographical locations and seasons (Staufenberger et al. 2008; Bengtsson et al. 2010). Studies assessing the harmful bacterial loads on other sea vegetables such as red macroalgae Porphyra or Palmaria should be encouraged and even examination of kelps of varying morphologies, including Alaria esculenta or the new taxonomically differentiated Saccharina angustissima, formerly Saccharina latissima forma angustissima, termed "skinny kelp" native to the Gulf of Maine (Augyte et al. 2019) may be beneficial. Knowledge of the time required for water column bacteria to incorporate into the biofilm of macroalgae would have important implications in decisions based on when to harvest following anthropogenic or environmental events that may increase bacterial load (Lu et al. 2008; Liu and Pang 2010). The winter-spring sampling season coincided with spring snowmelt and rain events that increased freshwater discharge from local rivers and terrestrial runoff and are often linked to increased fecal bacteria levels in coastal waters (Online Resource B; Prasad et al. 2015; Tilburg et al. 2015; Jokinen et al. 2009).

\section{Influence of siting}

Much of the variation in plating data among sampling events was in part due to sampling at different sites. This study did not show a significance difference in bacterial quantities between sites, but this could be an important avenue for further research. Differences in bacterial presence among sites would provide support for selecting sites for kelp aquaculture based on evaluations of local sources that could affect bacteriological water quality. With further research, influences of point pollution sources should not be overlooked when choosing sites of macroalgal cultivation or harvest. Sources could be wastewater discharge, freshwater outputs, waterfowl presence, or resuspension of bacteria from sediments or wrack lines, all of which may have affected the results of this study (Lévesque et al. 2000; Martinez-Urtaza et al. 2004; Yamahara et al. 2012; Malham et al. 2014). Local watershed differences could have attributed to differing bacterial loads within runoff entering the two bays and dilution and transport of runoff or discharge upon entering coastal waters (Baudart et al. 2000; Walters et al. 2011; Sassoubre et al. 2015; Mattioli et al. 2017). Local precipitation events may influence the presence of fecal bacteria on kelp, but increased sampling efforts are needed to more clearly parse out this relationship and potentially 
schedule when harvests would be safe post-rainfall events. More frequent observations of combined environmental data and bacterial abundances are needed for statistical analyses of any relationships that may exist.

\section{Recommendations and conclusion}

This study of kelp collected from several sites of aquaculture during February-May 2018 detected the presence of the human pathogens $S$. Typhimurium, enterohemorrhagic E. coli, and $V$. parahaemolyticus through qPCR analysis with primers specific for virulence. Food safety guidelines regarding the growing, harvesting, and processing of kelp and other macroalgal species may need to vary depending on the level of processing of the product as macroalgae are currently consumed raw or frozen, dried, or incorporated into value-added products (Perry et al. 2019). Identifying the effects of different processing methods on the bacterial load on sea vegetables would be a valuable next step to establish initial bacterial levels allowable on harvested kelp and aid in further development of best management and harvesting strategies to minimize bacterial contamination. Implementation of hazards analysis and critical control points (HACCP) plans could be an effective starting point, such as requiring $<2 \mathrm{~h}$ exposure of kelp to ambient temperature prior to processing as suggested for the northeast USA state of CT (Yarish et al. 2017). States have Vibrio Control Plans already set in place to protect shellfish from the growth of $V$. parahaemolyticus, such as the state of ME, USA requiring shellfish to be delivered within $18 \mathrm{~h}$ of harvest during summer months (beginning May 1; ME DMR 2018b); a rule that should be tested and considered for sea vegetables. To create best practices that protect food safety and consider the realities of macroalgae harvest and transport, tiered approaches to regulating for bacterial growth based on the end food product may be beneficial to the industry. Further study is required to properly determine the levels of food safety risk connected with these pathogens on kelp. Experimentation to optimize DNA extraction from samples may improve qPCR detection of low bacterial concentrations and eliminate the microbiological enrichment step used in this study so that PCR-mediated quantification of pathogen load would be possible.

The consistent qPCR and plating detection of these bacteria on kelp from March-May suggests that harvesting from farms later in this growing season does not increase the risk of fecal bacteria or Vibrio as sometimes thought to be associated with increased precipitation, temperature, and local shore use commonly seen in May in this region. Yet, further study into the influences of environmental factors and local point sources of pollution on bacterial loads found on harvested kelp would further determine the importance of specific site selections and temporal practices for kelp aquaculture. The plating detections of E. coli and Vibrio on kelp in concentrations which varied from those in water sampled from the surface and at $2 \mathrm{~m}$ depth raise questions involving the association of these bacteria with kelp tissue and support the continuation of direct sampling of the kelp tissue in future studies. This study indicates the importance of regular bacterial water quality monitoring for waters where kelp is cultured and implementation of plans to control for bacterial growth on harvested product. Additionally, it shows a need for similar studies with different sites of macroalgal culture or wild harvest to determine how the presence of these bacterial pathogens may change based on algal species and location.

Acknowledgments We wish to thank Dr. Zachary Olson for his aid with statistical analyses, and Tollef Olsen and Gretchen Grebe for making sampling collection possible. We acknowledge and thank Mary Hollandbeck who contributed to the development of this study through preliminary work. This research was conducted in part of the requirements for a Master's degree in the School of Marine Programs at the University of New England.

Funding information This work was funded by the National Science Foundation award no. IIA-1355457 to the University of Maine and the College of Arts and Sciences and Arthur P. Girard Marine Science Center at the University of New England.

\section{Compliance with ethical standards}

Conflict of interest The authors declare that they have no conflict of interest.

Open Access This article is distributed under the terms of the Creative Commons Attribution 4.0 International License (http:// creativecommons.org/licenses/by/4.0/), which permits unrestricted use, distribution, and reproduction in any medium, provided you give appropriate credit to the original author(s) and the source, provide a link to the Creative Commons license, and indicate if changes were made.

\section{References}

Augyte S, Lewis L, Lin S, Neefus CD, Yarish C (2019) Speciation in the exposed intertidal zone: the case of Saccharina angustissima comb. nov. \& stat. nov. (Laminariales, Phaeophyceae). Phycologia 57:100 112

Baker-Austin C, Trinanes JA, Taylor NGH, Hartnell R, Siitonen A, Martinez-Urtaza J (2013) Emerging Vibrio risk at high latitudes in response to ocean warming. Nat Clim Change 3:73-77

Baudart J, Grabulos J, Barusseau JP, Lebaron P (2000) Salmonella spp. and fecal coliform loads in coastal waters from a point vs. nonpoint source of pollution. J Environ Qual 29:241-250

Bäumler A, Heffron F, Reissbrodt R (1997) Rapid detection of Salmonella enterica with primers specific for iroB. J Clin Microbiol 35:1224-1230

Bengtsson MM, Sjøtun K, Øvreås L (2010) Seasonal dynamics of bacterial biofilms on the kelp Laminaria hyperborea. Aquat Microb Ecol 60:71-83 
Bisha B, Simonson J, Janes M, Bauman K, Goodridge LD (2012) A review of the current status of cultural and rapid detection of $V$ parahaemolyticus. Int J Food Sci Technol 47:885-899

Blaser MJ, Newman LS (1982) A review of human salmonellosis: I. Infective dose. Rev Infect Dis 4:1096-1106

Blikra M, Løvda T, Vaka M, Roiha IS, Lunestad BT (2019) Assessment of food quality and microbial safety of brown macroalgae (Alaria esculenta and Saccharina latissima). J Sci Food Agric 99:11981206

Bourdoux S, Li D, Rajkovic A, Devlieghere F, Uyttendaele M (2016) Performance of drying technologies to ensure microbial safety of dried fruits and vegetables. Compr Rev Food Sci F 15:1056-1066

Boyd KG, Adams DR, Burgess JG (1999) Antibacterial and repellent activities of marine bacteria associated with algal surfaces. Biofouling 14:227-236

Brands DA, Inman AE, Gerba CP, Maré CJ, Billington SJ, Saif LA, Levine JF, Joens LA (2005) Prevalence of Salmonella spp. in oysters in the United States. Appl Environ Microbiol 71:893-897

Cole A, Langston A, Davis C, Belle S, McConnon J, Gabe T (2017) Maine aquaculture economic impact report. The University of Maine Aquaculture Research Institute. https://umaine.edu/ aquaculture/wp-content/uploads/sites/134/2017/01/AquacultureEcon-Report.pdf. Accessed 3 June 2019

Cox S, Abu-Ghannam N, Gupta S (2010) An assessment of the antioxidant and antimicrobial activity of six species of edible Irish seaweeds. Int Food Res J 17:205-220

DePaola A, Hopkins LH, Peeler JT, Wentz B, McPhearson RM (1990) Incidence of Vibrio parahaemolyticus in US coastal waters and oysters. Appl Environ Microbiol 56:2299-2302

Duan D, Xu L, Fei X, Xu H (1995) Short communication: marine organisms attached to seaweed surfaces in Jiaozhou Bay, China. World J Microbiol Technol 11:351-352

Dubber D, Harder T (2008) Extracts of Ceramium rubrum, Mastocarpus stellatus and Laminara digitata inhibit growth of marine and fish pathogenic bacteria at ecologically realistic concentrations. Aquaculture 274:196-200

Dufour AP, Strickland ER, Cabelli VJ (1981) Membrane filter method for enumerating Escherichia coli. Appl Environ Microbiol 41:11521158

Duinker A, Roiha IS, Amlund H, Dahl L, Lock EJ, Kögel T, Måge, A, Lunestad BT (2016) Potential risks posed by macroalgae for application as feed and food- a Norwegian perspective. National Institute of Nutrition and Seafood Research (NIFES). https://www. mattilsynet.no/mat_og_vann/produksjon_av_mat/fisk_og_sjomat/ rapport_makroalger_2016_nifes.23097/binary/Rapport\% 20makroalger\%202016\%20Nifes. Accessed 3 June 2019

Flavin K, Flavin N, Flahive B (2013) Kelp farming manual: a guide to the processes, techniques, and equipment for farming kelp in New England waters. Ocean Approved. https://static1.squarespace.com/ static/52f23e95e4b0a96c7b53ad7c/t/52f78b0de4b0374e6a0a4da8/ 1391954701750/OceanApproved_KelpManualLowRez.pdf. Accessed 3 June 2019

Fukushima H, Tsunomori Y, Seki R (2003) Duplex real-time SYBR green PCR assays for the detection of 17 species of food- or waterborne pathogens in stools. J Clin Microbiol 41:5134-5416

Gupta S, Rajauria G, Abu-Ghannam N (2010) Study of the microbial diversity and antimicrobial properties of Irish edible brown seaweeds. Int J Food Sci Technol 45:485-489

Hafting JT, Craigie JS, Stengel DB, Loureiro RR, Buschmann AH, Yarish C, Edwards MD, Critchley AT (2015) Prospects and challenges for industrial production of seaweed bioactives. J Phycol 51:821-883

Hassard F, Andrews A, Jones DL, Parsons L, Jones V, Cox BA, Daldorph P, Brett H, McDonald JE, Malham SK (2017) Physiochemical factors influence the abundance and culturability of human enteric pathogens and fecal indicator organisms in estuarine water and sediment. Front Microbiol 8:1996
Jokinen CC, Schreier H, Mauro W, Taboada E, Issac-Renton JL, Topp E, Edge T, Thomas JE, Gannon VP (2009) The occurrence and sources of Campylobacter spp, Salmonella enterica, and Escherichia coli O157:H7 in the Salmon River, British Columbia, Canada. J Water Health 8:374-386

Jones S, Summer-Brason B (1998) Incidence and detection of pathogenic Vibrio sp. in a northern New England estuary, USA. J Shellfish Res 17:1665-1669

Kay D, Crowther J, Stapleton CM, Wyer MD, Fewtrell L, Edwards A, Francis CA, McDonald AT, Watkins J, Wilkinson J (2008) Faecal indicator organism concentrations in sewage and treated effluents. Water Res 42:442-454

Kobayashi T, Enomoto S, Sakazaki R, Kuwahara S (1963) A new selective medium for pathogenic vibrios, TCBS (modified Nakanishi's agar). J Bacteriol 18:387

Labbé RG, Garcia S (2013) Guide to foodborne pathogens. WileyBlackwell, West Sussex

Lachnit T, Meske D, Wahl M, Harder T, Schmitz R (2011) Epibacterial community patterns on marine macroalgae are host-specific but temporally variable. Environ Microbiol 13:655-665

Lachnit T, Fischer M, Künzel S, Baines JF, Harder T (2013) Compounds associated with algal surfaces mediate epiphytic colonization of the marine macroalga Fucus vesiculosus. FEMS Microbiol Ecol 84: $411-420$

Letchumanan V, Chan K, Lee LH (2014) Vibrio parahaemolyticus: a review on the pathogenesis, prevalence, and advance molecular identification techniques. Front Microbiol 5:705

Lévesque B, Brousseau P, Bernier F, Dewailly E, Joly J (2000) Study of the bacterial content of ring-billed gull droppings in relation to recreational water quality. Water Res 34:1089-1096

Liot F, Colin A, Mabeau S (1993) Microbiology and storage life of fresh edible seaweeds. J Appl Phycol 5:243-247

Lipp EK, Kurz R, Vincent R, Rodriguez-Palacios C, Farrah SR, Rose JB (2001) Effects of seasonal variability and weather on microbial fecal pollution and enteric pathogens in a subtropical estuary. Estuaries 24:266-276

Liu F, Pang S (2010) Nonculturability of the pathogenic Vibrio parahaemolyticus in live culture of Grateloupia turuturu is associated with bacterial attachment to algal thalli. Acta Oceanol Sin 29: 92-103

Lu K, Lin W, Liu J (2008) The characteristics of nutrient removal and inhibitory effect of Ulva clathrata on Vibrio anguillarum. J Appl Phycol 20:1061-1068

Mahmud ZH, Kassu A, Mohamma A, Yamato M, Bhuiyan NA, Nair GB, Ota F (2006) Isolation and molecular characterization of toxigenic Vibrio parahaemolyticus from the Kii Channel, Japan. Microbiol Res 161:25-37

Mahmud ZH, Neogi SB, Kassu A, Huong BT, Jahid IK, Iqbal KJ, Islam MS, Ota F (2008) Occurrence, seasonality and genetic diversity of Vibrio vulnificus in coastal seaweeds and water along the Kii Channel, Japan. FEMS Microbiol Ecol 64:209-218

Mahoney JC, Gerding MJ, Jones SH, Whistler CA (2010) Comparison of the pathogenic potentials of environmental and clinical Vibrio parahaemolyticus strains indicates a role for temperature regulation in virulence. Environ Microbiol 76:7459-7465

Malham SK, Rajko-Nenow P, Howlett E, Tuson KE, Perkins TL, Pallet DW, Wang H, Jago CF, Jones DL, McDonald JE (2014) The interaction of human microbial pathogens, particulate matter and nutrients in estuarine environments and their impacts on recreational and shellfish waters. Environ Sci Process Impacts 16:2145-2155

Mallin MA, Williams KE, Esham EC, Lowe RP (2000) Effect of human development on bacteriological water quality in coastal watersheds. Ecol Appl 10:1047-1056

Martinez-Urtaza J, Saco M, Novoa J, Perez-Piñerio P, Peiteado J, Lonzano-Leon A, Garcia-Martin O (2004) Influence of environmental factors and human activity on the presence of Salmonella 
serovars in the marine environment. Appl Environ Microbiol 70: 2089-2097

Mattioli MC, Sassoubre LM, Russel TL, Boehm AB (2017) Decay of sewage-sourced microbial source tracking markers and fecal indicator bacteria in marine waters. Water Res 108:106-114

Maugeri TL, Carbone M, Fera MT, Irrera GP, Gugliandolo C (2004) Distribution of potentially pathogenic bacteria as free living and plankton associated in a marine coastal zone. J Appl Microbiol 97: 354-361

ME DMR: Maine Department of Marine Resources (2018a) Growing Area Bacterial Closure Notices with Maps for Areas No. 10:13. https://www.maine.gov/dmr/shellfish-sanitation-management/ closures/pollution.html. Accessed 3 June 2019

ME DMR: Maine Department of Marine Resources (2018b) New time temperature requirements- Guidance document. https://www.maine. gov/dmr/shellfish-sanitation-management/vibrio.html. Accessed 3 June 2019

Meillisa A, Siahaan EA, Park JN, Woo HC, Chun BS (2013) Effect of subcritical water hydrolysate in the brown seaweed Saccharina japonica as a potential antibacterial agent on food-borne pathogens. J Appl Phycol 25:763-769

Michelou VK, Caporaso JG, Knight R, Palumbi SR (2013) The ecology of microbial communities associated with Macrocystis pyrifera. PLoS One 8:e67480

Moore JE, Xu J, Millar BC (2002) Diversity of the microflora of edible macroalga (Palmaria palmata). Food Microbiol 19:249-257

Nevers M, Byappanahalli M, Phanikumar M, Whitman R (2016) Fecal indicator organism modeling and microbial source tracking in environmental waters, p 3.4.6-1-3.4.6-16. In: Yates M, Nakatsu C, Miller R, Pillai S (eds) Manual of Environmental Microbiology, Fourth edn. ASM Press, Washington, DC

Newton A, Kendall M, Vugia DJ, Henao OL, Mahon BE (2012) Increasing rates of vibriosis in the United States, 1966-2010: Review of surveillance data from 2 Systems. Clin Infect Dis 54: S391-S395

NSSP: National Shellfish Sanitation Program (2017) Guide for the Control of Molluscan Shellfish: 2017 Revision. United States Food and Drug Administration (FDA). https://www.fda.gov/ media/117080/download. Accessed 3 June 2019

Oliver JD (2005) The viable but nonculturable state in bacteria. J Microbiol 43:93-100

Parveen S, Hettiarachchi KA, Bowers JC, Jones JL, Tamplin ML, McKay R, Beatty W, Brohawn K, DaSilva LV, DePaola A (2008) Seasonal distribution of total and pathogenic Vibrio parahaemolyticus in Chesapeake Bay oysters and waters. Int J Food Microbiol 128: 354-361

Perry JJ, Brodt A, Skonberg DI (2019) Influence of dry salting on quality attributes of farmed kelp (Alaria esculenta) during long-term refrigerated storage. LWT Food Sci Technol 114:108362

Postollec F, Falentin H, Pavan S, Combrisson J, Sohier D (2011) Recent advances in quantitative PCR (qPCR) applications in food microbiology. Food Microbiol 28:848-861

Prasad VR, Srinivas TNR, Sarma VV (2015) Influence of river discharge on abundance and dissemination of heterotrophic, indicator and pathogenic bacteria along the east coast of India. Mar Pollut Bull 95:115-125

Rodriguez-Castro A, Ansede-Barmejo J, Blanco-Aba V, Verela-Pet J, Garcia-Martin O, Martinez-Urtaza J (2010) Prevalence and genetic diversity of pathogenic populations of Vibrio parahaemolyticus in coastal waters of Galicia, Spain. Environ Microbiol Rep 2:58-56

Sassoubre LM, Yamahara KM, Boehm AB (2015) Temporal stability of microbial community in sewage-polluted seawater exposed to natural sunlight cycles and marine microbiota. Appl Environ Microbiol 81:2107-2116

Savichtcheva O, Okabe S (2006) Alternative indicators of fecal pollution: relations with pathogens and conventional indicators, current methodologies for direct pathogen monitoring and future application perspectives. Water Res 40:2463-2476

Scallan E, Hoekstra RM, Angulo FJ, Tauxe RV, Widdowson MA, Roy SL, Jones JL, Griffin PM (2011) Foodborne illness acquired in the United States- major pathogens. Emerg Infect Dis 17:7-15

Sharpe AE, Jackson AK (1972) Stomaching: a new concept in bacteriological sample preparation. Appl Microbiol 24:175-178

Shehane SD, Harwood VJ, Whitlock JE, Rose JB (2004) The influence of rainfall on the incidence of microbial faecal indicators and the dominant sources of faecal pollution in a Florida river. J Appl Microbiol 98:1127-1136

Staufenberger T, Thiel V, Wiese J, Imhoff JF (2008) Phylogenetic analysis of bacteria associated with Laminaria saccharina. FEMS Microbiol Ecol 64:65-77

Su YC, Liu C (2007) Vibrio parahaemolyticus: a concern of seafood safety. Food Microbiol 24:549-558

Tantillo GM, Fontanarosa M, Di Pinto A, Musti M (2004) Updated perspectives on emerging vibrios associated with human infections. Lett Appl Microbiol 39:117-126

Thomas AC, Pershing AJ, Friedland KD, Nye JA, Mills KE, Alexander MA, Record NR, Weatherbee R, Henderson ME (2017) Seasonal trends and phenology shifts in sea surface temperature on the North American northeastern continental shelf. Elem Sci Anth 5:48

Tilburg CE, Jordan LM, Carlson AE, Zeeman SI, Yund PO (2015) The effects of precipitation, river discharge, land use and coastal circulation on water quality in coastal Maine. R Soc Open Sci 2:140429

Turner JW, Good B, Cole D, Lipp EK (2009) Plankton composition and environmental factors contribute to Vibrio seasonality. ISME J 3: 1082-1092

U.S. FDA: United States Food and Drug Administration (2018) Standards for the growing, harvesting, packing, and holding of produce of human consumption: guidance for the industry [Draft Guidance]. https://www.fda.gov/regulatory-information/search-fdaguidance-documents/draft-guidance-industry-standards-growingharvesting-packing-and-holding-produce-human-consumption. Accessed 3 June 2019

U.S. FDA: United States Food and Drug Administration (2019) Standards for the growing, harvesting, packing, and holding of produce for human consumption https://www.fda.gov/food/foodsafety-modernization-act-fsma/fsma-final-rule-produce-safety\# intro. Accessed 3 June 2019

Urquhart EA, Jones SH, Yu JW, Schuster BM, Marcinkiewicz AL, Whistler CA, Cooper VS (2016) Environmental conditions associated with elevated Vibrio parahaemolyticus concentrations in Great Bay Estuary, New Hampshire. PLoS One 11:e0155018

Vatsos IN, Rebours C (2015) Seaweed extracts as antimicrobial agents in aquaculture. J Appl Phycol 27:2017-2035

Vugia DJ, Shefer AM, Douglas J, Greene KD, Bryant RG, Werner SB (1997) Cholera from raw seaweed transported from the Philippines to California. Clin Microbiol 35:284-285

Walters SP, Thebo AL, Boehm AB (2011) Impact of urbanization and agriculture on the occurrence of bacterial pathogens and stx genes in coastal waterbodies of central California. Water Res 45:1752-1762

Wang G, Shuai L, Li Y, Lin W, Zhao X, Duan D (2008) Phylogenetic analysis of epiphytic marine bacteria on Hole-Rotten diseased sporophyte of Laminaria japonica. J Appl Phycol 20:403-409

Wang G, Chang L, Zhang R, Wang S, Wei X, Rickert E, Krost P, Xiao L, Weinberger F (2019) Can targeted defense elicitation improve seaweed aquaculture? J Appl Phycol 3:1845-1854

Watkins WD, Cabelli VJ (1985) Effect of fecal pollution on Vibrio parahaemolyticus densities in an estuarine environment. Appl Environ Microbiol 49:1307-1313

Weiskel PK, Howes BL, Heufelder GR (1996) Coliform contamination of a coastal embayment: sources and transport pathways. Environ Sci Technol 30:1872-1881 
Wells ML, Potin P, Craigie JS, Raven JA, Merchant SS, Helliwell KE, Smith AG, Camire ME, Brawley SH (2016) Algae as nutritional and functional food sources: revisiting our understanding. J Appl Phycol 29:949-982

Wiese J, Thiel V, Nagel K, Staufenberger T, Imhoff JF (2009) Diversity of antibiotic-active bacteria associated with the brown alga Laminaria saccharina from the Baltic Sea. Mar Biotechnol 11:287-300

Wu J, Long SC, Das D, Dorner SM (2011) Are microbial indicators and pathogens correlated? A statistical analysis of 40 years of research. J Water Health 9:265-278

Wyer MD, Kay D, Watkins J, Davies C, Kay C, Thomas R, Porter J, Stapleton CM, Moore H (2010) Evaluating short term changes in recreational water quality during a hydrograph event using a combination of microbial tracers, environmental microbiology, microbial source tracking and hydrological techniques: a case study in Southwest Wales, UK. Water Res 44:4783-4795
Xu F, Ilyas S, Hall JA, Jones SH, Cooper VS, Whistler CA (2015) Genetic characterization of clinical and environmental Vibrio parahaemolyticus from the Northeast USA reveals emerging resident and non-indigenous pathogen lineages. Front Microbiol 7:272

Yamahara KM, Sassoubre LM, Goodwin KD, Boehm AB (2012) Occurrence and persistence of bacterial pathogens and indicator organism in beach sand along the California coast. Appl Environ Microbiol 78:1733-1745

Yarish C, Kim JK, Lindell S, Kite-Powell H (2017) Developing an environmentally and economically sustainable sugar kelp aquaculture industry in southern New England: from seed to market. http:// opencommons.uconn.edu/eeb_articles/38. Accessed 3 June 2019

Publisher's note Springer Nature remains neutral with regard to jurisdictional claims in published maps and institutional affiliations. 